\title{
Economic Governance Quality and Chinese OFDI: Evidence from the "Belt and Road" Countries
}

\author{
Suhang Xu, Liyan Liu* \\ Beijing Institute of Petrochemical Technology, School of Economics and Management, Beijing, China \\ Email: *lucyliuliyan@bipt.edu.cn
}

How to cite this paper: $\mathrm{Xu}, \mathrm{S}$. H., \& Liu, L. Y. (2022). Economic Governance Quality and Chinese OFDI: Evidence from the "Belt and Road" Countries. Modern Economy, 13, 23-36.

https://doi.org/10.4236/me.2022.131002

Received: May 19, 2021

Accepted: January 3, 2022

Published: January 6, 2022

Copyright (อ 2022 by author(s) and Scientific Research Publishing Inc. This work is licensed under the Creative Commons Attribution International License (CC BY 4.0).

http://creativecommons.org/licenses/by/4.0/

\section{(c) (i) Open Access}

\begin{abstract}
China's foreign direct investment in 54 countries along the "Belt and Road" from year 2003 to year 2019 are adopted as sample data, and economic system indicators such as business freedom, currency freedom, trade freedom, investment freedom, and fiscal freedom are introduced as the proxy variable for the quality of host-country's economic governance, to analyze the impact of different economic governance levels of countries along the route on China's foreign direct investment. Due to the missing data and the non-random characteristics of China's investment in sample countries, the Heckman two-step model is adopted to solve the issue of self-selection bias, and policy impact of the "Belt and Road" initiative is introduced to explore the quality of economic governance of the countries along the route on China's foreign direct investment. The findings show that, 1) China is more inclined to invest in host countries with a large market, and its investment preference is market-seeking; 2) the host-country labor freedom and financial freedom have a positive impact on Chinese direct investment, while trade freedom and investment freedom negatively affects Chinese investment; 3 ) the implementation of the "Belt and Road" initiative has affected the mechanism of host-country's economic governance on China's foreign direct investment.
\end{abstract}

\section{Keywords}

Insert Economic Governance, Chinese OFDI, the "Belt and Road"

\section{Introduction}

Since the "Belt and Road" initiative was put forward, governments at all levels in China have continuously improved various policies and promoted investment. ${ }^{*}$ Corresponding author. 
At the same time, since the "Belt and Road" initiative partners are mostly emerging economies and developing countries, and their economic development levels and geographic environments are quite different and complex, which has brought potential risks to China's investments in the region.

Currently, few studies focus on the impacts of economic governance of countries along the "Belt and Road" on China's investment. The existing research mainly discusses the influence of the political system of the countries along the route on China's foreign investment, mainly targeting the political risks and the political system of the host country (Blonigen, 2005; Buckley, 2007). The hostcounty's political environment, potential political risks and bilateral political relations presented an impact on Chinese investment. However, most studies have neglected host-county's economic governance level, and there is still no theoretical basis that can directly reflect Chinese investment's operating costs and the operability degree of economic regulation. This status quo brings certain limitations to the analysis of the impact of the institutional environment on China's investment.

The impact of a country's economic governance on foreign investment behavior is directly reflected in the country's business environment, specifically in terms of property rights registration, contract execution, business disputes, bankruptcy resolution, and business registration. According to the 2019 Global Business Environment Report, there are still obvious imperfections in the regulation and rules of business activities in countries along the "Belt and Road", and various indicators are clearly behind the world average. There are problems in contract enforcement, business dispute resolution, property rights registration, bankruptcy resolution, import and export procedures, etc., which increase the probability of investment risks. In this context, the cost of Chinese investment in the "Belt and Road" countries is increasing. It is of strategic importance to study the impact of economic system and operating environment of host countries on China's investment, hence improving the layout of Chinese outward investment.

We focused on the economic governance quality of countries along the "Belt and Road" and introduced economic governance indicators such as business freedom, currency freedom, trade freedom, investment freedom and fiscal freedom as core variables, and analyzed the impact of economic governance of countries along the route on Chinese investment which is committed to discussing the optimization of Chinese investment layout from the perspective of host-country economic governance, and promoting the implementation of the "Belt and Road" initiative. The elimination of self-selection bias and the analysis of policy impact of the "Belt and Road" initiative is the major contributions of the study, however, since the study focused on the macro-level, the firm level study should be furthered in the future to obtain a more micro-perspective on this topic.

The rest of the study is organized as follows: II. Literature review; III. Model specification and data description; IV. Empirical analysis; V. Conclusions and suggestions. 


\section{Literature Review}

Existing research mainly focuses on the analysis of the impact of institutional quality on the location choice of China's foreign direct investment and believes that institutional quality is the decisive factor for foreign direct investment.

Early research focused on the analysis of the relationship between institutional quality and foreign direct investment. Blonigen (2005) believed that institutional quality is reflected in the property rights system, market system, and political system, which indirectly affects foreign direct investment. When the quality of the host country's political system, the legal system and the property rights system are not perfect, it will affect investment behavior; the quality of the institutional environment and market system will affect government's rent-seeking and corruption behavior. A negative system will increase the cost of investment in the country, thereby inhibiting investment activities.

Regarding the impact of institutional quality on location selection of Chinese investment, Cheung and Qian (2009) took China's investment in 50 countries with different institutional quality as sample data from year 1991 to year 2005, and found that institutional quality presents no significant impact on Chinese investment location selection. Diego (2011) gave the same research results, which proved the credibility of this conclusion. Yuanfei Kang et al. (2012) focused on the variability and complexity of institutional factors and found that the impact of institutional factors on Chinese investment showed diverse characteristics according to various host countries and time periods, therefore presented differentiated impacts on Chinese investments. Jiang Guanhong (2012) used Chinese investment data in 107 developing countries, studied the relations between host-country's regime stability, level of supervision, qualities of laws and regulations and Chinese direct investment. Findings show that the more stable the political power of the host country, the greater the government's supervision, and the more attractive to China's foreign investment. Chinese investment is more willing to invest in countries with high regulatory quality and less corruption. Zhang Jifeng (2013) found that Chinese companies are more willing to invest in countries with higher institutional quality.

Regarding the relationship between the institutional environment and the scale of foreign investment, Wei Junliang et al. (2009) analyzed the relationship between the political system environment of the host country and the scale of China's foreign direct investment and found that the greater the political risk of the host country, the greater risks such as embezzlement and illegal deprivation of equity. Host country political risks tend to further inhibit China's foreign investment activities and behaviors and reduce the scale of China's direct investment. Therefore, the political risk of the host country is significantly negatively correlated with the scale of China's foreign direct investment. Related study by Pan Zhen and Jin Zhongkun (2015) gave the same results. Deng Ming (2012) took China's foreign direct investment data in 73 countries from year 2000 to 2009 as sample data for analysis, found that for developing countries with low 
political risks, China has a good investment trend and a huge investment scale, however, this feature is not obvious in developed countries with higher institutional quality.

In terms of the impact of bilateral agreements with the host country on China's foreign investment, Zhang Yanhui et al. (2016) measured the political risks of the host country from 12 factors, through specific analysis of the impact of these factors on Chinese companies' foreign direct investment, found that host country's government stability and corruption control have a significant impact on China's foreign direct investment. The three factors as socioeconomic conditions, investment returns, and laws and regulations have a certain impact on Chinese direct investment of enterprises. Host country's political risk assessment system should be established, and bilateral treaties to protect investment should be established with more countries and regions. From the perspective of the institutional environment, Zhang Yueran and Fei Jin (2020) used panel data of China's outward direct investment in 113 countries and regions from year 2003 to 2017, applied the gravity model and systematic GMM method to further explore the impact of bilateral investment agreements on the location choice of China's direct investment. It is confirmed that bilateral investment agreements have a significant role in promoting China's foreign direct investment, and it is concluded that China's foreign direct investment has the characteristics of "institutional risk appetite". Bilateral investment agreements can make up for the host country's inefficient institutional environment, and bilateral agreements have a more significant promoting role in developing countries as in Asia, Latin America, than in developed countries as in Europe.

In addition, many scholars have tried to study China's investment by combining host country factors and corporate heterogeneity factors. Liu Xiaoning (2018) conducted a study combining host country factors and corporate heterogeneity factors, and found that enterprise productivity, enterprise scale, $R \& D$ investment and other variables have a significant positive impact on investment decisions, while the host country market scale, natural resources and institutional environment variables also have a significant role in location decision. The host country's tax level, labor cost, cultural distance and geographic distance variables have a negative impact on the probability of investment decision. Chinese companies are more inclined to invest in countries and regions with larger market scale, richer natural resources, better institutional environment, lower tax rates, lower labor costs, and closer cultural and geographic distances. Zhao Yunhui et al. (2020) found that the institutional environment, enterprise heterogeneity and the host country's economic endowment conditions have a comprehensive effect on investment promoting. The host country's natural resources, market size, and institutional environment are important external tractions for Chinese direct investment, and corporate production efficiency is an important internal driving force.

The existing research mostly analyzes the location choice of China's foreign 
direct investment from the perspective of political system, and most of them ignore the influence of economic system. Based on this, we adopt China's outward direct investment in countries along the "Belt and Road" as sample data to analyze the impact of the quality of economic systems in the countries along the route on the location choice and investment scale of China's outward direct investment. Since there are issues as time periods selection and non-randomness of the sample, we use Heckman two two-step model to solve the problem of sample selection bias. In the analysis and testing process, not only factors such as market size, market opportunities, market growth rate, and economic stabilities are considered, but also the policy factors of the "Belt and Road" initiative and its impact on China's foreign investment are introduced.

\section{Model Specification and Data Description}

1) Model specification

According to the "Statistical Bulletin of China's Outward Foreign Direct Investment", China's foreign direct investment in countries along the "Belt and Road" is discontinuous, and some data are missing. Because in the process of investing in countries along the "Belt and Road", multiple factors such as host country's economy, political environment, and investment environment will be considered comprehensively. In some countries or regions, the value of investment in a specific period may sometimes appear to be zero, and sometimes even the phenomenon of negative value appears ${ }^{1}$, which is not randomly generated, but the result of the strategic investment decision, therefore, the discontinuity in the sample data is not random. This kind of non-random absence will lead to the problem of sample selection bias. Therefore, here we use the Heckman two-step model to solve the problem of sample selection bias. The specific model settings are as follows:

$$
\begin{aligned}
\operatorname{Pr}\left(\text { OFDI }_{i t}\right)= & \Phi\left(\gamma Z_{i t}\right) \\
= & W\left(\alpha_{0}+\alpha_{1} \text { Bufree }_{i t}+\alpha_{2} \text { Labfree }_{i t}+\alpha_{3} \text { Monfree }_{i t}\right. \\
& +\alpha_{4} \text { Tradfree }_{i t}+\alpha_{5} \text { Invfree }_{i t}+\alpha_{6} \text { Finfree }_{i t}+\alpha_{7} \text { polgov }_{i t} \\
& \left.+\sum \alpha_{k} X_{i t}+\mu_{\text {country }}+\mu_{\text {year }}+\varepsilon_{i t}\right) \\
\text { OFDI }_{i t}= & \alpha_{0}+\alpha_{1} \text { Bufree }_{i t}+\alpha_{2} \text { Labfree }_{i t}+\alpha_{3} \text { Monfree }_{i t}+\alpha_{4} \text { Tradfree }_{i t} \\
+ & \alpha_{5} \text { Invfree }_{i t}+\alpha_{6} \text { Finfree }_{i t}+\alpha_{7} \text { polgov }_{i t}+\beta\left(\gamma Z_{i t}\right) \\
+ & \sum \alpha_{k} X_{i t}+\mu_{\text {country }}+\mu_{\text {year }}+\varepsilon_{i t} \\
X_{i t}=\lambda_{0}+ & \lambda_{1} \text { Ingdp }_{i t}+\lambda_{2} \text { Ingdpper }_{i t}+\lambda_{3} \text { Ingdpgrow }_{i t}+\lambda_{4} \text { Ingdpdef }_{i t}+\mu_{i t}
\end{aligned}
$$

Among them, $O F D I_{i t}$ represents the data of China's outward direct investment in the $i$-th countries along the route in year $j ;$ Bufree $_{i t}$ represents for business freedom, Labfree $_{i t}$ is labor freedom, Monfree $_{i t}$ is currency freedom,

${ }^{1}$ Here the volume of China's foreign investment is the difference between capital outflows and capital inflows. If the volume of inflows in that year is greater than the volume of outflows, there will be a negative value. 
Tradfree $_{i t}$ is trade freedom, Invfree ${ }_{i t}$ is investment freedom, Finfree ${ }_{i t}$ is fiscal freedom, using the economic freedom index published by the Heritage Foundation. polgov ${ }_{i t}$ is the political governance quality of the host country.

$X_{i t}$ are control variables. $\operatorname{lngdp_{it}}$ is the market size of the host country, expressed by the GDP of the countries along the route; Ingdpper ${ }_{i t}$ is the market opportunity of the host country, expressed by the per capita GDP of the countries along the route; lngdpgrow ${ }_{i t}$ is the market potential of the host country, expressed by the GDP growth rate of the countries along the route; Ingdpdef $_{\text {it }}$ is the market stability of the host country, expressed by the host country's GDP parity index.

$\beta$ is the coefficient of the inverse Mills ratio. When the value is not equal to 0 , it means that the model has a sample self-selection problem, which can be effectively solved by the Heckman two step model; $\mu_{\text {country }}$ means country fixed effect; $\mu_{\text {year }}$ means time fixed effect; $\varepsilon_{i t}$ and $\mu_{i t}$ are random disturbances.

2) Variable and data description

Economic governance quality and quality of political systems are used as core variables, host-country's market size, market opportunities, market growth rate and economic stability are introduced as control variables.

For Foreign direct investment data, we use China's direct investment volume in countries along the "Belt and Road" from year 2003 to 2019². Here 54 countries along the "Belt and Road" 3 are chosen as sample data, which covers 99\% of China's direct investment in countries along the "Belt and Road". The data comes from the "Statistical Bulletin of China's Outward Foreign Direct Investment" published by the Ministry of Commerce of China.

The core variables include index variable for economic governance quality and political system quality. Data of host-country's economic governance quality comes from the Economic Freedom Index published by the American Heritage Foundation ${ }^{4}$, which can systematically measure and compare the economic freedom of various countries or regions in the world. Here we use six main indicators: business freedom, labor freedom, trade freedom, fiscal freedom, currency freedom, and investment freedom. The commercial freedom of the countries along the route can be a good measure for the difficulty of business registration

\footnotetext{
${ }^{2}$ Since the freedom index and GDP data of most countries along the route have been updated to year 2019 up to the study is made, we hereby choose the sample data from year 2003 to year 2019.

${ }^{3}$ According to the status of Chinese OFDI in the "Belt and Road" countries, countries as Brunei, Myanmar, Iraq, the Syrian Arab Republic, Palestine, Bhutan, Afghanistan, Maldives, Moldova, Montenegro, Turkey are not included in this study.

${ }^{4}$ The economic freedom index proposed by the American Foundation was proposed in the late 1980s and started to be implemented in 1995 . It has been widely used by countries all over the world as a weathervane for observing the economic conditions of various countries. The index's score ranges from 0 to 100 , where the higher the score, the freer the economy of the country. According to the scores, the economic freedom of the surveyed country is divided into five different economic freedom ranges, 80 - 100 points represent "free economy", 60 - 79 points represent "comparatively free economy", 60 - 69 points represent "medium free economy", 50 - 59 points represent "comparatively less free economy", and points less than 50 represents "repressed economy". Due to the availability of data, five indicators of the host country's business freedom, currency freedom, investment freedom, investment freedom, and fiscal freedom are used for scoring and pacing as the host country's economic freedom index.
} 
and establishment. The trade freedom index measures host-country's trade import and export tariff policy, trade barriers and the easiness of trade activities. Fiscal freedom is related to the actual interests of each citizen of the countries along the route, and effectively measures the taxation situation of government departments, such as the relationship between personal income tax and corporate income tax and gross national product. The degree of currency freedom and investment freedom are good measures of host country's economic environment in terms of domestic price stability and capital mobility.

Due to the non-linear characteristics of the political system, the measurement of political system quality has always been an important problem in empirical research, and no indicator can measure the quality of the system completely and accurately. Here we use the current six commonly used indicators to characterize political system factors: political stability, government service efficiency, government supervision, investment laws and regulations, government corruption control, and discourse accountability. The average calculation of these six indicators is used.

The control variables in the model include market size, market potential, market opportunities, and economic stability. For market size, we use GDP to represent the gross domestic product of the host country, and the logarithm is used to measure the market size of the host country. Market potential is measured by the market growth rate, here we use variable GDPGROW represents the growth rate of the host country's market growth rate, and the logarithm form is used. While GDPPER is the per capita GDP of the host country, represents the market opportunity, and the logarithm is used. The data comes from the World Bank's World Development Index Standards Database, and all value of the control variables are converted into constant 2010 USD prices. While economic stability is represented by GDPDEF, which is measured by the GDP deflator of the host country.

It can be seen from Table 1 that the average range of the five indicators for the quality of economic governance in countries along the "Belt and Road" is 0.5011 to 3.2061 . Since they are standardized to the value range of 0 to 10 , the value range of 0.5011 to 3.2061 indicating that the overall economic governance quality of those countries is low, and there are great differences among countries.

\section{Empirical Analysis}

1) The problem of multicollinearity

Before conducting an empirical test of the impact of economic governance quality on China's foreign direct investment, it is necessary to test the multi-collinearity between the core variables of various economic governance indexes. Here the Variance Inflation Factor (VIF) method is used. Results are shown in Table 2.

It can be seen from Table 2 that the variance expansion factors of fiscal freedom and investment freedom are relatively large, respectively 3.91 and 3.12, but 
Table 1. Statistical characteristics of variables.

\begin{tabular}{|c|c|c|c|c|c|c|}
\hline Variable & description & Obs & Mean & Std. Dev. & Min & Max \\
\hline lnofdi & & 651 & 3.2061 & 2.6691 & -4.6052 & 9.2546 \\
\hline bufree & & 918 & 0.6538 & 0.1293 & 0.2920 & 1.0000 \\
\hline labfree & & 918 & 0.6329 & 0.1344 & 0.2000 & 1.0000 \\
\hline monfree & & 918 & 0.7479 & 0.0905 & 0.1410 & 0.9300 \\
\hline tradfree & & 918 & 0.7598 & 0.1153 & 0.0000 & 0.9480 \\
\hline invfree & & 918 & 0.5041 & 0.2135 & 0.0000 & 0.9000 \\
\hline finfree & & 918 & 0.5011 & 0.1942 & 0.1000 & 0.9000 \\
\hline polgov & & 918 & -0.1337 & 0.7155 & -2.0002 & 1.6354 \\
\hline $\operatorname{lngdp}$ & & 918 & 25.1496 & 2.0580 & 22.0076 & 36.5347 \\
\hline gdpper & & 918 & 11.5266 & 2.6095 & 5.9222 & 19.1427 \\
\hline gdpgrow & & 918 & 4.5130 & 4.4257 & -27.9944 & 34.4662 \\
\hline gdpdef & & 918 & 1.5131 & 3.9192 & 0.0866 & 63.7691 \\
\hline
\end{tabular}

Table 2. VIF test.

\begin{tabular}{ccc}
\hline Variable & VIF & $1 / \mathrm{VIF}$ \\
\hline finfree & 3.91 & 0.2560 \\
invfree & 3.12 & 0.3207 \\
monfree & 2.99 & 0.3347 \\
bufree & 1.98 & 0.5044 \\
tradfree & 1.76 & 0.5685 \\
labfree & 1.74 & 0.5748 \\
gdpdef & 1.41 & 0.7113 \\
lngdp1 & 1.37 & 0.7315 \\
gdpper & 1.18 & 0.8464 \\
gdpgrow & 1.17 & 0.8560 \\
polgov & 1.17 & 0.8578 \\
Mean VIF & 1.98 & \\
\hline
\end{tabular}

still far less than 10. Therefore, there is no obvious multicollinearity problem among the variables in the model.

2) Without the policy impact of the "Belt and Road" Initiative

Table 3 shows the test results of investment preference test and investment model test for the Heckman two-step model. It can be seen from Table 3 that the $\mathrm{P}$ value of the inverse Mills ratio is 0.001 , indicating that there is a sample self-selection problem, and the Heckman two-stage model needs to be used. 
Table 3. Heckman two-step model without policy impact of the "Belt and Road" initiative.

\begin{tabular}{|c|c|c|c|c|c|c|}
\hline lnofdi & Coef. & Std.Err. & $\mathrm{z}$ & $\mathrm{P}>\mathrm{z}$ & [95\% onf.] & [Interval] \\
\hline \multicolumn{7}{|l|}{ lnofdi } \\
\hline bufree & 3.4924 & 2.9089 & 1.20 & 0.230 & -2.2089 & 9.1936 \\
\hline labfree & 3.8763 & 2.4060 & 1.61 & 0.107 & -0.8395 & 8.5920 \\
\hline monfree & 2.4032 & 4.5798 & 0.52 & 0.600 & -6.5731 & 11.3794 \\
\hline tradfree & 4.1987 & 3.0201 & 1.39 & 0.164 & -1.7206 & 10.1180 \\
\hline invfree & -1.4430 & 2.3052 & -0.63 & 0.531 & -5.9612 & 3.0751 \\
\hline finfree & 1.4641 & 2.6794 & 0.55 & 0.585 & -3.7875 & 6.7156 \\
\hline polgov & -1.5507 & 0.7701 & -2.01 & 0.044 & -3.0601 & -0.0413 \\
\hline _cons & -2.2498 & 4.5811 & -0.49 & 0.623 & -11.2285 & 6.7290 \\
\hline \multicolumn{7}{|l|}{ select } \\
\hline lngdp1 & 0.1475 & 0.0261 & 5.65 & 0.000 & 0.0963 & 0.1987 \\
\hline gdpper & 0.0366 & 0.0181 & 2.02 & 0.043 & 0.0011 & 0.0721 \\
\hline gdpgrow & 0.0167 & 0.0101 & 1.65 & 0.099 & -0.0031 & 0.0365 \\
\hline gdpdef & 0.0021 & 0.0111 & 0.19 & 0.848 & -0.0197 & 0.0239 \\
\hline _cons & -3.6274 & 0.6454 & -5.62 & 0.000 & -4.8923 & -2.3625 \\
\hline \multicolumn{7}{|l|}{ mills } \\
\hline lambda & -9.8360 & 2.8920 & -3.40 & 0.001 & -15.5041 & -4.1677 \\
\hline rho & -1.0000 & & & & & \\
\hline sigma & 9.8360 & & & & & \\
\hline
\end{tabular}

Ignoring the impact of the "Belt and Road" policy and only considering the impact of economic governance, political system environment and market factors on China's foreign direct investment are shown in Table 3, from which we can find the coefficient between China's foreign direct investment and market size is significantly positive, which shows that China's outward direct investment is significantly positively correlated with the host country's market size, market opportunities, and market growth rate, indicating that China's outward investment in countries along the "Belt and Road" is market-seeking. The coefficient between the host country's market opportunities and market growth rate and China's foreign direct investment is relatively small, indicating that China's investment in countries along the "Belt and Road" is relatively less affected by market opportunities and market growth rate. The relationship between the economic stability and Chinese investment is insignificant, indicating that the economic stability is not the major factor to be considered by Chinese investment.

There is a significant negative correlation between the political system envi- 
ronment and China's direct investment. Countries with a stable political environment and greater corruption control seems to be more attractive to China's capital inflow. This shows that Chinese investment along the "Belt and Road" countries has a kind of risk appetite.

The test results of the five economic governance variables show that there is no statistically significant relationship between the five economic governance factors and Chinese investment. China's direct investment is less affected by host-country's economic governance.

3) With the policy impact of the "Belt and Road" initiative

To further analyze the impact of the core variables and control variables on China's foreign direct investment taking the implementation of the "Belt and Road" initiative into account, we divided the model testing period into two subperiods, as year 2003 to year 2013, and year 2013 to year 2019. Results are shown in Table 4.

It can be seen from Table 4 that after the introduction of the "Belt and Road" initiative, the correlation between China's foreign direct investment and the

Table 4. Table 3 Heckman two-step model with policy impact of the "Belt and Road" initiative.

\begin{tabular}{|c|c|c|c|c|c|c|}
\hline \multirow{2}{*}{ lnofdi } & \multicolumn{3}{|c|}{$2003-2013$} & \multicolumn{3}{|c|}{ 2013-2019 } \\
\hline & Coef. & Std. Err. & $\mathrm{P}>\mathrm{z}$ & Coef. & Std. Err. & $\mathrm{P}>\mathrm{z}$ \\
\hline \multicolumn{7}{|l|}{ lnofdi } \\
\hline bufree & 2.5007 & 1.7049 & 0.142 & -0.0718 & 1.4514 & 0.961 \\
\hline labfree & 4.9285 & 1.3691 & 0.000 & 4.5508 & 1.2234 & 0.000 \\
\hline monfree & 0.9354 & 2.5314 & 0.712 & 1.5695 & 2.3172 & 0.498 \\
\hline tradfree & 2.3651 & 1.5546 & 0.128 & -5.5453 & 2.3275 & 0.017 \\
\hline invfree & -3.5647 & 1.3787 & 0.010 & -5.3130 & 1.0810 & 0.000 \\
\hline finfree & 2.3817 & 1.4802 & 0.108 & 2.8848 & 1.4259 & 0.043 \\
\hline polgov & -1.2904 & 0.4504 & 0.004 & 0.2002 & 0.3633 & 0.581 \\
\hline _cons & -2.4613 & 2.5677 & 0.338 & 7.2635 & 2.5773 & 0.005 \\
\hline \multicolumn{7}{|l|}{ select } \\
\hline lngdp1 & 0.3091 & 0.0403 & 0.000 & 0.0366 & 0.0373 & 0.326 \\
\hline gdpper & 0.0782 & 0.0237 & 0.001 & -0.0146 & 0.0304 & 0.630 \\
\hline gdpgrow & 0.0078 & 0.0115 & 0.495 & 0.1114 & 0.0271 & 0.000 \\
\hline gdpdef & 0.0662 & 0.0351 & 0.059 & 0.0010 & 0.0126 & 0.939 \\
\hline _cons & -8.1273 & 1.0300 & 0.000 & -0.4461 & 0.8843 & 0.614 \\
\hline \multicolumn{7}{|l|}{ mills } \\
\hline lambda & -4.4536 & 0.8873 & 0.000 & -2.8276 & 1.1659 & 0.005 \\
\hline rho & -1.0000 & & & -1.0000 & & \\
\hline sigma & 4.4536 & & & 2.8276 & & \\
\hline
\end{tabular}


model's control variables has not been changed much. China's outward direct investment still shows a significant positive correlation with host-country's market size and market growth rate. Before the implementation of the "Belt and Road" initiative, China's investment had a significant positive relation with the host country's market opportunities; after the implementation of the initiative, it had a negative relationship with market opportunities. After the introduction of the "Belt and Road" policy initiative, China's outbound investment has a positive correlation with market stability, but the correlation coefficient is relatively small, indicating that after considering the "Belt and Road" policy, market stability has a relatively small impact on China's outbound investment. In general, before and after the implementation of the initiative, China's investment both present market-seeking objectives, and both are inclined to invest in countries with faster growth rate of GDP per capita.

Political governance factors show negative impacts on China's outbound investment before the initiative, indicating a risk appetite for China's outbound investment, which is consistent with the situation where the "Belt and Road" initiative was not considered. While after the implementation of the "Belt and Road" initiative, the impact of political governance on China's foreign investment has become insignificant.

The test results between the quality of economic governance and China's foreign direct investment show that the introduction of the "Belt and Road" initiative has a significant impact on three economic governance indicators. Before and after the implementation of the "Belt and Road" initiative, labor freedom has a significant positive correlation with Chinese investment, and the correlation coefficient is relatively large, indicating that Chinese investments prefer to invest in countries and regions with a high degree of labor freedom; investment freedom negatively impact China's foreign investment before and after the "Belt and Road" initiative, indicating that high freedom of capital in and out of the host country will negatively impact on Chinese investment; fiscal freedom has shown a significantly positive impact on China's foreign investment after the "Belt and Road" initiative; commercial freedom and currency freedom are both statistically insignificant in situations in situations of without and with the policy impact of the "Belt and Road" initiative.

\section{Conclusions and Suggestions}

Based on China's direct investment in 54 countries along the "Belt and Road", the Heckman two-stage model is applied and economic governance indicators such as commercial freedom, currency freedom, trade freedom, investment freedom, and fiscal freedom are introduced to analyze the impact of different economic governance levels of host countries on China's foreign direct investment. Results show:

1) China is more inclined to invest in host countries with a large market size, and its investment preference is market-seeking. The host country's labor free- 
dom index and financial freedom are positively correlated with China's outward direct investment, while trade freedom and investment freedom are negatively correlated with China's investment. 2) China's foreign investment in countries along the "Belt and Road" has certain characteristics of risk appetite before the implementation of the "Belt and Road" initiative, and after the initiative, with the improvement of host countries' political environment, the effect of political system on Chinese investment became insignificant. 3) Since the implementation of the "Belt and Road" initiative, the relationship between economic governance indicators and China's outward direct investment has changed. The implementation of the "Belt and Road" initiative has affected the mechanism of host-country's economic governance on China's foreign direct investment. Chinese enterprises should choose countries with high economic governance levels such as good indicators of labor freedom and financial freedom to reduce the probability of investment risks and promote the sustainable development of foreign direct investment.

As the existing economic, political, and legal systems of the countries along the route have been established for a long time, it is difficult to change according to the needs of Chinese investment enterprises. In this context, Chinese investment enterprises should rely on their own governments to establish a sound investment system, avoid investment risks caused by changes in host-country's economic environment, and achieve long-term, continuous investment returns. Accordingly, we put forward the following suggestions.

1) To further Improve foreign investment consulting services

To encourage domestic surplus capital to flow to the international market, Chinese government should provide foreign investment enterprises with information services on investment projects in countries along the route, including legal, political, and economic information on the host country, and establish a corresponding information database and convenient information communication and transmission channels to improve outbound investment advisory service system. For example, departments concerned should set up foreign agencies and service departments to publish and update information on all levels of the investment field of the host country; establish investment evaluation agencies to control and analyze the feasibility and potential risks of enterprise investment projects.

2) To further enhance the legal system related to foreign investment

Improve the legal system related to foreign investment and provide legal protection for enterprises' foreign investment. Before entering the host country for investment, Chinese enterprises must be familiar with local laws and regulations and have a thorough understanding of the sensitive issues such as property rights, funding disputes, and geopolitics to avoid falling into the trap of double taxation. In this regard, investment enterprises can take advantage of the protection of bilateral investment protection agreements, join concerning investment guarantees and dispute settlement conventions, and actively carry out communications to reduce the information costs for rights and interests protection. Profes- 
sional legislation in the field of multinational investment should be actively carried out and legal assistance to enterprises should be provided.

3) To further promote the safety protection for outward investment

The countries along the "Belt and Road" have complex geological environments and relatively imperfect legal systems, hence Chinese investment enterprises may face various risks in host countries. The governments of various levels should attach importance to host-countries' economic and political conditions, establish friendly cooperative relations with local governments, and create a stable and safe investment environment for outward investment enterprises. At the same time, cooperation with financial institutions of countries along the route can be built to form financial platforms to provide enterprises with capital safety and property protection, and insurance funds can also be established to solve financial security issues that may arise during the investment process.

Finally, investment enterprises should also actively obtain information concerning the laws and regulations of the host country, establish an investment risk concept and control corporate risks.

\section{Supporting Projects}

Coordinated Development Mechanism of Firm's domestic and overseas Investment, Beijing URT Project (2020J00045).

\section{Conflicts of Interest}

The authors declare no conflicts of interest regarding the publication of this paper.

\section{References}

Blonigen, B. A. (2005). A Review of the Empirical Literature on FDI Determinants. Atlantic Economic Journal, 33, 383-403. https://doi.org/10.1007/s11293-005-2868-9

Buckley, P. J., Clegg, L. J., Cross, A. R., et al. (2007). The Determinants of Chinese Outward Foreign Direct Investment. Journal of International Business Studies, 38, 499-518. https://doi.org/10.1057/palgrave.jibs.8400277

Cheung, Y. W., \& Qian, X. (2009). Empirics of China's Outward Direct Investment. Pacific Economic Review, 14, 312-341. https://doi.org/10.1111/j.1468-0106.2009.00451.x

Deng, M. (2012). Institutional Distance, "Demonstration Effect" and the Location Distribution of OFDI in China. International Trade Issues, 2, 123-135.

Diego, Q. (2011). Enrique Claver. Laura Rienda. Political Risk, Cultural Distance and Outward Foreign Direct Investment: Empirical Evidence from Large Chines Firms. Asia Pacific Journal of Management, 4, 1-16.

Jiang, G. H., Jiang, D. C. (2012). Location Selection of China’s Outward Investment: Panel Data Test Based on Investment Gravity Model. World Economy, 9, 21-40.

Kang, Y. F., \& Jiang, F. M. (2012). FDI Location Choice of Chinese Multinationals in East and Southeast Asia: Traditional Economic Factors and Institutional Perspective. Journal of World Business, 47, 45-53. https://doi.org/10.1016/j.jwb.2010.10.019

Liu, X. N. (2018). Location Choice of Enterprises' Direct Investment Abroad-Combined Investigation of Host Country Factors and Enterprise Heterogeneity Factors. Economic 
Survey, 35, 59-66.

Pan, Z., \& Jin, Z. K. (2015). Bilateral Political Relations, Host Country System Risk and China's Foreign Direct Investment. Finance and Trade Economy, 6, 85-97.

Wei, J. L., \& Chen, L. G. (2009). The Impact of Political Risk on Chinese Companies Going Global-An Empirical Study Based on Panel Data Model. Journal of Zhejiang Gongshang University, 96, 53-61.

Zhang, J. F. (2013). Institutional Factors, Resource Seeking and Location Selection of China's Foreign Direct Investment. Industrial Technology \& Economy, 9, 56-62.

Zhang, Y. H., Du, N. R., Li, Z. W., \& Shi, Q. (2016). Research on the Impact of National Political Risk on My Country'S Foreign Direct Investment-Empirical Evidence from 112 Countries. Investment Research, 35, 19-30.

Zhang, Y. R., \& Fei, J. (2020). Bilateral Investment Agreements, Host Country Institutional Environment and China's Outward Direct Investment Location Selection. Forum of World Economics and Politics, 6, 116-141.

Zhao, Y. H., Tao, K. T., Li, Y. H., \& Li, X. H. (2020). Location Choice of Chinese Enterprises' Outward Direct Investment-A Study on Linkage Effect Based on QCA Method. China Industrial Economy, 11, 118-136. 